\title{
Three-Decade Evolution of the Willingness to Defend One's Own Country: the Case of the Baltic States
}

\begin{abstract}
This article provides the most comprehensive analysis of the willingness to defend one's own country in the similar, yet different, Baltic States: Estonia, Latvia, and Lithuania. It reviews the previous research focussing on regularities explaining the willingness to defend the country. This article proceeds with mapping the results of the previous sociological research from the three countries and discusses the results of a nationally representative poll conducted for the purposes of this research.

The previous and current data suggests that Estonians are more likely to defend their country, while Latvians and Lithuanians are less keen to do so. In a wider regional and global context, the willingness to defend one's own country is high in Estonia but low in Lithuania.

Several hypotheses on regularities are tested in the Baltic case. It is affirmed that on the inter-societal level, growth in life opportunities tends to have a negative effect on the willingness to defend one's own country, though it cannot explain the correlation of fluctuations in both indicators. On the intrasocietal level, it is affirmed that men are more likely to defend their own country. While the empirical data in relation to two of the Baltic States confirm some other hypotheses, such as those related to trust in the armed forces, the impact of external threats, and historical experiences, there is no conclusive support in all three regarding other factors like trust in the government, religiousness, conscription, age, nor education on the individual level. That underlines the role of various factors, interaction thereof and their different effect on people's willingness to defend their countries.
\end{abstract}

\section{Introduction}

The issue of the willingness of individuals to defend their own countries remains relevant in the constantly evolving security environment. The prevalence of armed conflicts across the globe invokes the importance of national and individual security. However, the individual preferences are increasingly

\footnotetext{
* $\operatorname{Dr}$ Māris Andžāns is an assistant professor at Rīga Stradiņš University, Faculty of European Studies. Address for correspondence: 16 Dzirciema Street, LV-1007 Riga, Latvia; phone: +371 67409261; e-mail: maris.andzans@rsu.lv

** Dr Andris Sprū ds is a professor at Rīga Stradiņš University, Faculty of European Studies. Address for correspondence: 16 Dzirciema Street, LV-1007 Rīga, Latvia; phone: +371 67409261;

e-mail: andris.spruds@rsu.lv
} 
shaped by a variety of traditional and emerging external and internal dynamics. An increasing digitalization, weaponization of the digital information space, and influence warfare campaigns may substantially shape choices of individuals, especially in the times of uncertainty. The evolving "hearts and minds" within society interact with other significant internal factors influencing willingness of individuals to defend their own country. Those combinations of individual perceptions and rationale and eventual choices directly correlate with defensibility of countries. Hence, the willingness of individuals to act matters enormously.

Willingness to defend one's own country and willingness to fight for one's country along with related notions like willingness to fight wars and willingness to support warfare has been subject to a substantial strand of research in political science and sociology. It has also broadly coincided with gradual increase of attention in security and defence research agenda towards the issues of the individual level and perceptions thereof. This article primarily focuses on the notions of the willingness to defend one's own country and the willingness to fight for one's country and uses these terms interchangeably in the context of the Baltic States. A more narrow conceptual focus notwithstanding the previous studies with relying on related notions of the willingness to fight wars and support for warfare are also reviewed in the following subsections. Such studies provide additional observations of causalities of individual-level preferences.

In terms of the willingness to defend one's own country, a considerable segment of the literature has focused on the interpretation of data acquired from global and/or regional-level surveys, most notably the World Values Survey $^{1}$ and the European Values Study. ${ }^{2}$ Most comprehensively, regularities on this issue are assessed by Inglehart, Puranen, and Welzel in their 2015 article (hereafter referred to as Inglehart et al.). ${ }^{3}$ This article essentially serves as a response to their call for further research in this field. ${ }^{4}$ It focuses on a particular research gap: by synthetizing the hypotheses and assumptions on causal mechanisms and testing them in a multi-state case study with nationally representative empirical data.

\footnotetext{
1 "Welcome to the World Values Survey site," Institute for Comparative Survey Research, accessed December 27, 2019, http://www.worldvaluessurvey.org.

2 "European Values Study," accessed December 27, 2019, https://europeanvaluesstudy.eu.

${ }^{3}$ Ronald F. Inglehart, Bi Puranen, and Christian Welzel, "Declining willingness to fight for one's country: The individual-level basis of the long peace," Journal of Peace Research 52, no. 4 (2015): 418-434.

${ }^{4}$ Inglehart et al., "Declining willingness to fight for one's country: The individual-level basis of the long peace," 432 .
} 
The three similar, yet different, Baltic States provide a unique case for analysis. First, they have undergone considerable political, economic, and societal transformation in almost three decades since their independence from the Soviet Union. Since regaining independence in 1991, they have acceded to the European Union (hereafter referred to as the EU) and NATO; they have joined the Eurozone and the Schengen Area, they are even more integrated in the EU than some other Member States. They also have advanced significantly in terms of economic development as well as freedoms and liberties enjoyed by the societies. This presents a solid and representative case for assessing the impact of growing life opportunities on the willingness to defend one's own country, a central issue in the study of Inglehart et al.

Second, all three countries have uneasy relations with Russia. The neighbour of all three of them is widely perceived as the main source of risks to their national security. ${ }^{5}$ The perception of threat has surged after the 2008 Russian-Georgian military conflict and has been increasing even more with the Russian-Ukrainian conflict evolving since 2014. Since then both more emphasis has been placed on the individual defence capabilities (including the non-military spheres) and the NATO Allies have established rotational military presence in all three countries. Previous literature in this field, most notably Inglehart et al., ${ }^{6}$ suggests that neighbouring countries entailing negative security dynamics are seen as a factor which underpins higher willingness to defend one's own country.

Third, while all three countries are often treated as a common regional unit, they are both similar and different. To name some of the differences, while Estonia has been more exposed to the Nordic influences in recent decades and occasionally has positioned itself as a Nordic (not Baltic) country, Lithuania has been more exposed to Central European influences. All three of them have pursued different approaches with their armed forces, including the recruitment practices within Estonia relying on conscription and Lithuania returning to a milder form of it recently. Also importantly, compared to Lithuania, both Estonia and Latvia have ethnically heterogeneous societies. Considerable parts of their populations are of Russian and other Eastern-Sla-

\footnotetext{
${ }^{5}$ Parliament of Estonia, National Security Concept of the Republic of Estonia (2017), http://www. kaitseministeerium.ee/sites/default/files/elfinder/article_files/national_security_concept_2017_0.pdf; Parliament of Latvia, The National Security Concept (2019), https:/www.mod.gov.lv/sites/mod/files/ document/NDK_ENG_final.pdf; Parliament of Lithuania, National Security Strategy of the Republic of Lithuania (January 17, 2017), https://kam.lt/download/57457/2017-nacsaugstrategijaen.pdf.

${ }^{6}$ Inglehart et al., "Declining willingness to fight for one's country: The individual-level basis of the long peace," 420.
} 
vic descent; ${ }^{7}$ their views often differ from most ethnic Estonians and Latvians, including those on the willingness to defend their respective countries they inhabit. ${ }^{8}$ Even though this aspect has been addressed in previous research, most notably and recently by Rutkauskas, ${ }^{9}$ it deserves further and more detailed attention in all three countries.

\section{Hypotheses on the willingness to defend one's country}

\subsection{Hypotheses of previous researches}

The complexity of interpreting the level of the willingness to fight for the country is underlined by Díez Nicolás “....as signs of militarism or antimilitarism, as signs of high or low citizen's consciousness and responsibility, or as signs of braveness and cowardice?"10 While underlining the need to strive for peaceful conduct of inter-state affairs, here we do not treat the willingness to defend one's own country as negative per se and not as an indicator of militarism, war-likeness, or aggressiveness. This is especially the case with small countries and small powers. Furthermore, governments tend to perceive the willingness to defend the respective country as positive and strive to increase that level of responsibility within national security frameworks. ${ }^{11}$

\footnotetext{
${ }^{7}$ Out of the population of Estonia, Estonians are 68.5 percent and Russians 24.8 percent (as of 2019); in Latvia - Latvians are 62.3 percent, Russians 24.9 percent, Belarussians 3.2 percent, Ukrainians 2.2 percent, and Poles 2 percent (as of 2019); in Lithuania - Lithuanians are 84.2 percent of inhabitants and Poles 6.6 percent and Russians 5.8 percent (as of results of 2011 census) ("Population by ethnic nationality, 1 January, years," Statistics Estonia, 2019, modified June 6, 2019, https://www.stat.ee/34278; "IRG069. Usually resident population by ethnicity at the beginning of the year," Central Statistical Bureau of Latvia, accessed December 27, 2019, http://datal.csb.gov.lv/pxweb/en/iedz/iedz_iedzrakst/IRG069.px/; "Ethnicity, mother tongue and religion," Statistics Lithuania, last modified March 15, 2013, https:/osp.stat.gov.lt/en/web/ guest/informaciniai-pranesimai?articleId=223122.).

${ }^{8}$ For example, polls from the defence ministries of Estonia and Latvia (Turu-uuringute, Public Opinion and National Defence, March 2019, http://www.kmin.ee/sites/default/files/elfinder/article_files/public_ opinion_and_national_defence_2019_march_0.pdf, 39; SKDS, Latvijas iedzīvotāju viedoklis par valsts aizsardzības jautājumiem, November 2016, https://www.mod.gov.lv/sites/mod/files/document/SKDS_ aptauja_2016\%20\%281\%29.pdf, 43 .

${ }^{9}$ Virgilijus Rutkauskas, "Factors Affecting Willingness to Fight for One’s Own Country: The Case of Baltic States," Special Operations Journal 4, no. 1 (2018): 48-62.

${ }^{10}$ Juan Díez-Nicolás, "Cultural Differences on Values about Conflict, War and Peace," in Religion, democratic values and political conflict, ed. Yilmaz Esmer, Hans-Dieter Klingemann, and Bi Puranen (Uppsala University, 2009): 259.

${ }^{11}$ For example, see: Parliament of Lithuania, National Security Strategy of the Republic of Lithuania, 15.
} 
This article does not address the democratic peace concept ${ }^{12}$ or the capitalistic peace concept ${ }^{13}$ where the former assumes that democracies almost never fight each other, while the latter states that prosperity and interdependence of modern democracies determine their peacefulness. In other words, the factors and assumptions of what contributes to conflicts between and among states are not in the focus of this research. Instead, it seeks to estimate and explain citizens' willingness to fight for their own country from a defensive perspective: why people are or are not willing to defend their countries in case of external aggression.

The most comprehensive research in this field has been conducted by Inglehart et al. in their collaborative and individual deliberations. Inglehart et al. put forth and tested four hypotheses based on the data collected by the World Values Survey and the European Values Study. First, based on the crosssectional aspect, societies with higher life opportunities and existential security level emphasize pro-choice values (measured as support to reproductive freedoms and homosexuality) and they demonstrate lower willingness to risk their lives in wars. Second, based on the longitudinal aspect, the stronger growth is in the pro-choice values, the sharper the decline in the willingness to endanger their lives. Third, based on the multi-level aspect, societies with more common pro-choice values inflict members of those societies with lower levels of willingness to imperil themselves. Fourth, based on the historical aspect, past humiliation in wars decreases the willingness to fight (under this hypothesis, they also mention the phenomenon of the Nordic countries, which is separately addressed below). All in all, Inglehart et al. argue that increased life opportunities contribute to higher valuation of lives and, accordingly, lead to a lower willingness to risk lives. ${ }^{14}$

The first two and the fourth hypotheses of Inglehart et al. can be classified as inter-societal. That is, both of them put forth assumptions on regularities at the societal (state) level and strive to explain why certain societies have higher or lower levels of the willingness to fight. Their third hypothesis focuses on the intra-societal or the individual level, i.e., the factors affecting the choice of individuals across different societies. Both types of hypotheses are not mutually exclusive. For example, a high level of national pride can be a

\footnotetext{
${ }^{12}$ See: Michael W. Doyle, "Liberalism and world politics," American Political Science Review 80, no. 4 (1986): 1151-69.

${ }^{13}$ See: Richard Rosecrance, The Rise of the Trading State: Commerce and Conquest in the Modern World (New York: Basic Books, 1987).

${ }^{14}$ Inglehart et al., "Declining willingness to fight for one's country: The individual-level basis of the long peace," 418, 421-2.
} 
predictive indicator in both of them. As argued below, higher levels of national pride in societies will most likely correlate with higher willingness to fight for one's own country, while individuals feeling higher national pride will most likely be more willing to do so than their compatriots with a less favourable view towards their country.

There are a couple of further inter-societal hypotheses which deserve closer attention. Based on the information of the World Values Survey and the European Values Study (1981 through 2005), Díez-Nicolás concludes that the level of national pride (and the level of confidence in the national armed forces) is the most accurate prognosticator for the willingness to fight for one's own country: the higher the national pride and confidence in the national armed forces, the higher the willingness to fight for the respective country in the event of a war. According to him, this trend is observed in countries with significant differences and it tends to be stable over long periods. ${ }^{15}$ Also $\mathrm{Pu}-$ ranen and Torgler underline the strong link between higher levels of national pride and trust in the armed forces and the willingness to fight. However, both of them emphasise this trend on the individual level, rather than on the state level; Torgler also adds here that the trust in the government and legal systems serve as indicators of higher levels of the willingness to go to war. ${ }^{16}$

Several studies note that the willingness to fight for one's country significantly depends on the historical, social, and political context of the country in question. Previous researches, including Inglehart et al. (their fourth hypothesis on the historical perspective), have found two groups of countries particularly standing out amongst others. These two groups are the World War Two Axis powers, Germany and Japan in particular, and the Nordic countries. In the case of the former group, the willingness to fight is low, ${ }^{17}$ while in the latter one it is higher than other hypotheses and indicators predict. ${ }^{18}$

The Nordic phenomenon is further addressed in detail by Inglehart

\footnotetext{
${ }^{15}$ Díez-Nicolás, “Cultural Differences on Values about Conflict, War and Peace," 264, 272.

${ }^{16}$ Bi Puranen, "Allegiance eroding: People's dwindling willingness to fight in wars," in The Civic Culture Transformed: From Allegiant to Assertive Citizens, ed. Russell J. Dalton, and Christian Welzel (New York: Cambridge University Press, 2015), 269, 276-7; Benno Torgler, "Why do people go to war?" Defence and Peace Economics 14, no. 4 (2003): 276.

${ }^{17}$ Inglehart et al., "Declining willingness to fight for one's country: The individual-level basis of the long peace," 420, 428; Bi Puranen, "Allegiance eroding: People’s dwindling willingness to fight in wars," 271; Díez-Nicolás, "Cultural Differences on Values about Conflict, War and Peace," 265; Torgler, "Why do people go to war?" 276; Christopher J. Anderson, Anna Getmansky, and Sivan Hirsch-Hoefler, "Burden sharing: income, inequality and willingness to fight," British Journal of Political Science (2018): 32.

${ }^{18}$ Inglehart et al., "Declining willingness to fight for one's country: The individual-level basis of the long peace," 420, 428; Bi Puranen, "Allegiance eroding: People’s dwindling willingness to fight in wars," 271; Torgler, "Why do people go to war?" 276.
} 
et al. and Puranen. They explain this with the emancipatory lifestyles of the Nordic societies and their location in vicinity of Russia (previously the Soviet Union, representing threats to that lifestyle) ${ }^{19}$ thus, the defence of a Nordic country is associated with the defence and promotion of the values dominant in the region. ${ }^{20}$ Similarly, Díez-Nicolás observed that entanglement in ongoing conflicts and external threats can raise the level of the willingness to fight for one's own country. ${ }^{21}$

Horowitz and Levendusky assessed the impact of conscription in supporting warfare (this factor deserves attention given the different approaches and discussions on this issue in the Baltic States). As their conclusions are based on an experiment in only one country, i.e., the United States of America, these results have to be treated with caution. They conclude that mandatory service reduces public support for wars. According to these authors, the most likely explanation is self-interest of individuals, in other words, preference not to risk their own lives as conscripts. ${ }^{22}$ Meanwhile, Anderson et al., referring to the article by Horowitz and Levendusky, note that the level of the willingness to fight is modestly higher in countries with conscription in place. ${ }^{23}$

Also regional, cultural, and socio-economic contexts have been assessed as determinates to either lower or higher the willingness to defend one's own country. Díez Nicolás concluded that the highest willingness to fight could be observed in (as he defined them) Asian Sino-Confucian, Islamic, and Sub-Saharan countries, while the level was the lowest in West European Catholic and Anglo-Saxon countries (he classified the Baltic States among the West European Protestant countries that principally demonstrated average levels of the willingness to fight). ${ }^{24} \mathrm{~A}$ WIN/Gallup International Global Survey from 2014 concluded that the highest willingness to fight for their country was in the combined Middle East \& Northern Africa region and in Asia (as well as among Muslims and Hindus in terms of religious affiliation), whereas it was the lowest one in Western Europe and North America (as well as among Protestants). ${ }^{25}$ Furthermore, Anderson et al. conclude that the willingness to fight for their

\footnotetext{
${ }^{19}$ Inglehart et al., "Declining willingness to fight for one's country: The individual-level basis of the long peace," 420.

${ }^{20}$ Bi Puranen, “Allegiance eroding: People’s dwindling willingness to fight in wars," 271.

${ }^{21}$ Díez-Nicolás, "Cultural Differences on Values about Conflict, War and Peace," 259, 261-2, 264.

${ }^{22}$ Michael C. Horowitz and Matthew S. Levendusky, "Drafting Support for War: Conscription and Mass Support for Warfare," The Journal of Politics 73, no. 2, (May 2011): 532.

${ }^{23}$ Anderson et al., "Burden sharing: income, inequality and willingness to fight," 32.

${ }^{24}$ Díez-Nicolás, “Cultural Differences on Values about Conflict, War and Peace," 262.

${ }^{25}$ WIN/Gallup International, WIN/Gallup International Global Survey Shows Three in Five Willing to Fight for Their Country, March 18, 2015, http://gallup.com.pk/wp-content/uploads/2015/12/1803151.pdf, 3.
} 
own country was lower in societies with higher income inequality in comparison to those with lower inequality levels. ${ }^{26}$

In the light of the researches focusing on the intra-societal or the individual level, it has often been observed that indicators such as gender and attitude towards the country were notable determining factors in terms of an individual's willingness to fight. While various studies tend to arrive at different conclusions on certain indicators (especially in region-specific researches), many have concluded that men were more likely to fight than women ${ }^{27}$ (some others also note younger age $\mathrm{e}^{28}$ and marital status ${ }^{29}$ ) as well as that individuals with a higher level of national pride and trust in the armed forces were willing to fight ${ }^{30}$ (some of them also noted the related trust in the government and the legal system as well as religiousness and ideological inclination towards the right). ${ }^{31}$ While the level of education has been often discussed as a factor in determining the views of individuals in this respect, Anderson et al. noted the lack of evidence for interrelationship between the education level of individuals and the willingness to fight for the country. ${ }^{32}$

Other pieces of literature have assessed the impact of socio-economic factors on individual choices. Anderson and Hirsch-Hoefler ${ }^{33}$ and Anderson et al. assessed the link between economic equality and the willingness to fight. The latter research, which was based on the data from the World Values Survey (data from 1981 to 2013), concluded that there was no difference in the willingness to fight among the rich and the poor in the societies with low levels of inequality, but the rich people become less willing to fight in comparison to the poor ones along with the growing inequality in the society (in their view, poo-

\footnotetext{
${ }^{26}$ Anderson et al. "Burden sharing: income, inequality and willingness to fight," 30-1.

${ }^{27}$ Inglehart et al., "Declining willingness to fight for one's country: The individual-level basis of the long peace," 28 (appendix); Torgler, "Why do people go to war?” 276; Bi Puranen, “Allegiance eroding: People’s dwindling willingness to fight in wars," 277; WIN/Gallup International, WIN/Gallup International Global Survey Shows Three in Five Willing to Fight for Their Country, 1.

${ }^{28}$ WIN/Gallup International, WIN/Gallup International Global Survey Shows Three in Five Willing to Fight for Their Country, 1; Torgler, "Why do people go to war?" 276.

${ }^{29}$ Anderson et al., "Burden sharing: income, inequality and willingness to fight," 31.

${ }^{30}$ Inglehart et al., "Declining willingness to fight for one's country: The individual-level basis of the long peace," 28 (appendix); Bi Puranen, "Allegiance eroding: People's dwindling willingness to fight in wars," 277; Torgler, "Why do people go to war?" 276; Anderson et al. "Burden sharing: income, inequality and willingness to fight," $5,31-2$.

${ }^{31}$ Torgler, "Why do people go to war?" 276.

${ }^{32}$ Anderson et al., "Burden sharing: income, inequality and willingness to fight," 32.

${ }^{33}$ Christopher J. Anderson, and Sivan Hirsch-Hoefler, "UNEQUAL SACRIFICE: Income, Inequality, and the Willingness to Fight Wars," Paper prepared for presentation at the Annual Meeting of the American Political Science Association, Washington, DC, September 2-5, 2010: 1-37. https://papers.ssrn.com/sol3/ papers.cfm?abstract_id=1644044\#\#.
} 
rer individuals are more prone to mobilize to fight). ${ }^{34}$ Finally, Torgler assessed the impact of divergence between benefits and costs in the willingness to go to war. He did not find sufficient evidence that calculation between benefits and costs significantly influenced the choice of individuals. In other words, individuals' choice to go to war was irrational. ${ }^{35}$

\subsection{Synthesis of hypotheses}

For the purpose of this article, deliberations from the previous subchapter are summarized and classified in hypotheses of two categories, with a focus on the further application to the case of the Baltic States. As explained in the previous sub-chapter, some elements of both categories overlap as the same factor can impact the situation at the both inter-societal and intra-societal levels. The context and focus of analysis, which these hypotheses are derived from, differ. Nevertheless, in our view, such a compilation method can facilitate further research agenda.

First, these are the inter-societal or the country-level hypotheses (H.1.[consecutive number]), which this article aims to test:

- H.1.1: Societies with higher life opportunities accentuate pro-choice values and demonstrate lower willingness to fight;

- H.1.2: Societies with higher levels of national pride, confidence in the national armed forces, and the government demonstrate higher levels of the willingness to fight;

- H.1.3: Societies humiliated in past wars demonstrate lower willingness to fight, while those subject to current external threats demonstrate higher levels of the willingness to fight;

- H.1.4: Societies with higher income inequality demonstrate lower willingness to fight.

Second, the following intra-societal or the individual level hypotheses (H.2.[consecutive number]) are tested against empirical evidence:

- H.2.1: Males with a higher level of national pride and confidence in their national armed forces and the government demonstrate higher levels of the willingness to fight;

0149 H.2.2: The rich individuals are less willing to fight than the poor ones in societies with a higher income inequality;

\footnotetext{
${ }^{34}$ Anderson et al., "Burden sharing: income, inequality and willingness to fight," 30-1.

${ }^{35}$ Torgler, "Why do people go to war?" 261, 276.
} 
- H.2.3: Individuals' choice to fight is irrational from the point of view of costs and benefits.

Although factors related to religiousness, age, education, ideological views, and conscription are also addressed in the previous sub-chapter, those conclusions are not sufficiently shared across the research agenda of the willingness to defend one's own country and therefore they are not central in this research. Nevertheless, as far as the available data allows, these factors will be reviewed in the final chapter of this article.

\section{The willingness to defend the Baltic States from the historical and contemporary point of view}

\subsection{Historical evolution}

The willingness to defend the Baltic States has been addressed by many sociological polls and analyses thereof. Within a broader global and regional context (Europe in this case), this issue is most notably addressed by the World Values Survey and the European Values Study surveys. Both of them provide consistent data based on commonly agreed questions (that are asked to respondents). At the same time, both surveys provide historically fragmented data on the three countries in question. The last occasion when all three of them were surveyed in the same year was in 1990, while they were still a part of the Soviet Union.

Among Baltic-centric researches, Rutkauskas' study from 2018 provides the most comprehensive and recent review of this issue. His analysis of the data from 1990 to 2015 demonstrates that the willingness to fight for the Baltic States is mainly determined by national pride, trust in the respective governments and national armed forces, as well as by satisfaction in terms of the country's financial situation (he made his conclusions based on the data from 1990 and 2011 for Estonia; 1990, 1997 and 2014 for Latvia; and 1990, 1997, 1999, 2005, 2010, 2014 and 2015 for Lithuania). ${ }^{36}$ Other Baltic-centric researches (single-country, bilateral, or trilateral) have touched upon the issue in a wider context. Vileikienè and Janušauskienè summarized and analysed data from 1990 to 2016 on Lithuania in the context of safety perception in

\footnotetext{
${ }^{36}$ Rutkauskas, "Factors Affecting Willingness to Fight for One's Own Country: The Case of Baltic States," 54-5.
} 
the Lithuanian society; ${ }^{37}$ Andžāns, Sprūds, and Bruğe (hereafter referred to as Andžanns et al.) analysed the willingness to defend Latvia based on a survey from 2017 in the context of psychological defence; ${ }^{38}$ Ramonaite, Petronytė-Urbonavičiené, Skirkevičius, and Vosylius (hereafter referred to as Ramonaite et al.) assessed the willingness to defend Lithuania in 2017 in the context of civil resistance. ${ }^{39}$

Figure 1 below maps publicly available data from 1990 to 2019. It includes data from the European Values Study in 1990 on all three Baltic States ${ }^{40}$ and in 1999 on Lithuania; ${ }^{41}$ the World Values Survey in 1996 on Estonia and Latvia, in 1997 on Lithuania, ${ }^{42}$ and in 2011 on Estonia; ${ }^{43}$ Spinter tyrimai survey in 2010 on Lithuania; ${ }^{44}$ Civic Empowerment Index survey in 2014 on Lithuania; ${ }^{45}$ a survey from the Subjective Security in a Volatile Geopolitical Context: Traits, Factors and Individual Strategies project in 2016 on Lithuania; ${ }^{46}$ surveys of the Ministry of Defence of Estonia (conducted by Turu-uuringute, Faktum uuringukeskus, and Saar Poll) from 2000 to 2019 on Estonia; ${ }^{47}$ WIN/Gallup

\footnotetext{
${ }^{37}$ Eglè Vileikiené, and Diana Janušauskiene, "Subjective Security in a Volatile Geopolitical Situation: Does Lithuanian Society Feel Safe?" Journal on Baltic Security 2, no. 2 (2016): 126.

${ }^{38}$ Māris Andžāns, Ilvija Bruğe and, Andris Sprūds, Psihologiiskā aizsardzība Latvijā: ievainojamības un iespējas (Riga: Latvian Institute of International Affairs, 2017), 17.

${ }^{39}$ Ainè Ramonaité, Leva Petronytė-Urbonavičienè, Paulius Skirkevičius, and Eugenijus Vosylius, Kas eitu ginti Lietuvos?: pilietinio pasipriešinimo prielaidos ir galimybès (Vilnius: Aukso žuvys, 2018).

${ }^{40}$ European Values Study, EVS 1990 - Variable Report Integrated Dataset (European Values Study and GESIS Data Archive for the Social Sciences), released September 30, 2013, http://dx.doi.org/ doi:10.4232/1.10790, 561 .

${ }^{41}$ European Values Study, EVS 1999 - Variable Report Integrated Dataset, https://dbk.gesis.org/dbksearch/ file.asp?file=ZA3811_cdb.pdf, 916.

42 "WVS Wave 3 (1995-1998)," World Values Survey (edited by Ronald F. Inglehart et al.; Madrid:

JD Systems Institute), last accessed December 27, 2019, http://www.worldvaluessurvey.org/

WVSDocumentationWV3.jsp.

${ }_{43} 3$ "WVS Wave 6 (2010-2014)," World Values Survey (edited by Ronald F. Inglehart et al.; Madrid:

JD Systems Institute), last accessed December 27, 2019, http://www.worldvaluessurvey.org/

WVSDocumentationWV6.jsp.

${ }^{44}$ Darius Sutkus, "Pilietis-gynèjas: norai ir galimybès," Karys 2053, no. 1 (2017): 31.

${ }^{45}$ The Civic Empowerment Index, http://www.civitas.lt/wp-content/uploads/2015/11/Summary_2014_PGI_

ENG-summary.pdf, 9.

${ }^{46}$ Vileikienè, and Janušauskienė, "Subjective Security in a Volatile Geopolitical Situation: Does Lithuanian Society Feel Safe?" 126.

${ }^{47}$ Turu-uuringute, Avalik arvamus ja riigikaitse, February 2001,

http://www.kmin.ee/sites/default/files/elfinder/article_files/avalik_arvamus_ja_riigikaitse_veebruar_2001. pdf, 9; Turu-uuringute, Avalik arvamus ja riigikaitse, June 2001,

http://www.kmin.ee/sites/default/files/elfinder/article_files/avalik_arvamus_ja_riigikaitse_juuni_2001.pdf, 8; Turu-uuringute, Avalik arvamus ja riigikaitse, October 2001,

http://www.kmin.ee/sites/default/files/elfinder/article_files/avalik_arvamus_ja_riigikaitse_oktoober_2001. pdf, 8;
} 
Turu-uuringute, Avalik arvamus ja riigikaitse, March 2002, http://www.kmin.ee/sites/default/files/elfinder/ article_files/avalik_arvamus_ja_riigikaitse_marts_2002.pdf, 8;

Turu-uuringute, Avalik arvamus ja riigikaitse, June 2002,

http://www.kmin.ee/sites/default/files/elfinder/article_files/avalik_arvamus_ja_riigikaitse_juuni_2002.pdf, 7; Turu-uuringute, Avalik arvamus ja riigikaitse, October 2002,

http://www.kmin.ee/sites/default/files/elfinder/article_files/avalik_arvamus_ja_riigikaitse_oktoober_2002.pdf, 9; Faktum Uuringukeskus, Avalik arvamus ja riigikaitse, February 2003,

http://www.kmin.ee/sites/default/files/elfinder/article_files/avalik_arvamus_ja_riigikaitse_veebruar_2003.pdf, 12; Faktum Uuringukeskus, Avalik arvamus ja riigikaitse, May/June 2003,

http://www.kmin.ee/sites/default/files/elfinder/article_files/avalik_arvamus_ja_riigikaitse_juuni_2003.pdf, 11; Faktum Uuringukeskus, Avalik arvamus ja riigikaitse, October 2003,

http://www.kmin.ee/sites/default/files/elfinder/article_files/avalik_arvamus_ja_riigikaitse_oktoober_2003.pdf, 12; Faktum Uuringukeskus, Avalik arvamus ja riigikaitse, February 2004,

http://www.kmin.ee/sites/default/files/elfinder/article_files/avalik_arvamus_ja_riigikaitse_veebruar_2004.pdf, 36; Faktum Uuringukeskus, Avalik arvamus ja riigikaitse, June 2004,

http://www.kmin.ee/sites/default/files/elfinder/article_files/avalik_arvamus_ja_riigikaitse_juuni_2004.pdf, 37;

Faktum Uuringukeskus, Avalik arvamus ja riigikaitse, October 2004,

http://www.kmin.ee/sites/default/files/elfinder/article_files/avalik_arvamus_ja_riigikaitse_oktoober_2004.pdf, 21; Faktum Uuringukeskus, Avalik arvamus ja riigikaitse, March 2005,

http://www.kmin.ee/sites/default/files/elfinder/article_files/avalik_arvamus_ja_riigikaitse_marts_2005.pdf, 41; Faktum Uuringukeskus, Avalik arvamus ja riigikaitse, June 2005,

http://www.kmin.ee/sites/default/files/elfinder/article_files/avalik_arvamus_ja_riigikaitse_juuni_2005.pdf, 41;

Faktum Uuringukeskus, Avalik arvamus ja riigikaitse, November 2005,

http://www.kmin.ee/sites/default/files/elfinder/article_files/avalik_arvamus_ja_riigikaitse_novem-

ber_2005.pdf, 51; Turu-uuringute, Avalik arvamus ja riigikaitse, May 2006,

http://www.kmin.ee/sites/default/files/elfinder/article_files/avalik_arvamus_ja_riigikaitse_mai_2006.pdf, 31;

Turu-uuringute, Avalik arvamus ja riigikaitse, October 2006,

http://www.kmin.ee/sites/default/files/elfinder/article_files/avalik_arvamus_ja_riigikaitse_oktoober_2006.pdf, 31;

Turu-uuringute, Avalik arvamus ja riigikaitse, December 2006,

http://www.kmin.ee/sites/default/files/elfinder/article_files/avalik_arvamus_ja_riigikaitse_detsem-

ber_2006.pdf, 42; Turu-uuringute, Avalik arvamus ja riigikaitse, January 2007,

http://www.kmin.ee/sites/default/files/elfinder/article_files/avalik_arvamus_ja_riigikaitse_jaanuar_2007.pdf, 31; Turu-uuringute, Avalik arvamus ja riigikaitse, July 2007,

http://www.kmin.ee/sites/default/files/elfinder/article_files/avalik_arvamus_ja_riigikaitse_juuli_2007.pdf, 35; Turu-uuringute, Avalik arvamus ja riigikaitse, August 2008,

http://www.kmin.ee/sites/default/files/elfinder/article_files/avalik_arvamus_ja_riigikaitse_august_2008.pdf, 29; Turu-uuringute, Avalik arvamus ja riigikaitse, January 2009,

http://www.kmin.ee/sites/default/files/elfinder/article_files/avalik_arvamus_ja_riigikaitse_jaanuar_2009.pdf, 25; Turu-uuringute, Avalik arvamus ja riigikaitse, May 2009,

http://www.kmin.ee/sites/default/files/elfinder/article_files/avalik_arvamus_ja_riigikaitse_mai_2009.pdf, 28; Turu-uuringute, Avalik arvamus ja riigikaitse, January 2010,

http://www.kmin.ee/sites/default/files/elfinder/article_files/avalik_arvamus_ja_riigikaitse_jaanuar_2010.pdf, 27;

Turu-uuringute, Avalik arvamus ja riigikaitse, September 2010,

http://www.kmin.ee/sites/default/files/elfinder/article_files/avalik_arvamus_ja_riigikaitse_septem-

ber_2010.pdf, 36; Turu-uuringute, Avalik arvamus ja riigikaitse, August 2011,

http://www.kmin.ee/sites/default/files/elfinder/article_files/avalik_arvamus_ja_riigikaitse_august_2011.pdf, 30; Saar Poll, Avalik arvamus ja riigikaitse, October 2011,

http://www.kmin.ee/sites/default/files/elfinder/article_files/avalik_arvamus_ja_riigikaitse_oktoober_2011.pdf, 27; Saar Poll, Public Opinion and National Defence, March 2012,

http://www.kmin.ee/sites/default/files/elfinder/article_files/public_opinion_and_national_defence_2012_ march.pdf, 29; Saar Poll, Avalik arvamus ja riigikaitse, October 2012,

http://www.kmin.ee/sites/default/files/elfinder/article_files/avalik_arvamus_ja_riigikaitse_oktoober_2012.pdf, 30;

Saar Poll, Public Opinion and National Defence, March 2013, 
International Global Survey in 2014 on Latvia; ${ }^{48}$ surveys for the Ministry of Defence of Latvia (conducted by SKDS) from 2014 to 2016 on Latvia; ${ }^{49}$ a survey for Andžāns et al. (conducted by SKDS) in 2017 on Latvia, ${ }^{50}$ a survey for Ramonaite et al. in 2017 on Lithuania; ${ }^{51}$ and a survey conducted for the purposes of this research (by Turu-uuringute, SKDS, and Baltijos Tyrimai) in 2019 on all three countries.

Compared to the mapping attitudes in the Baltic States by Rutkauskas, Figure 1 adds data from 42 surveys conducted for the Estonian Ministry of Defence (2000 through 2019), three surveys conducted for the Latvian Ministry of Defence (2014 through 2016), one survey from the research of Andžāns et al. (2018), as well as the survey conducted for this research.

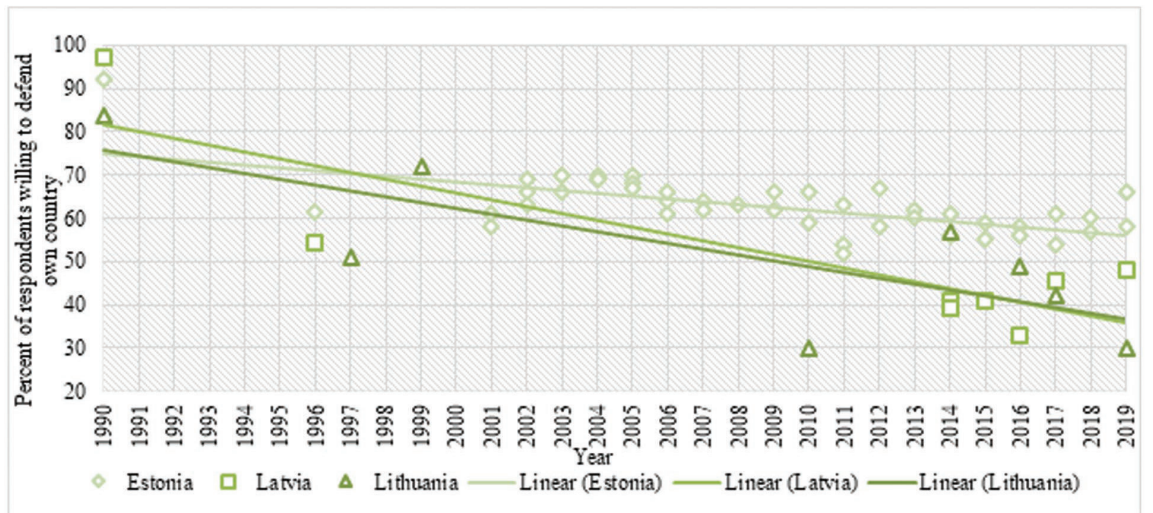

Figure 1. The willingness to defend one's own country in Estonia, Latvia, and Lithuania. ${ }^{52}$

\footnotetext{
${ }^{47} \mathrm{http} / / /$ www.kmin.ee/sites/default/files/elfinder/article_files/public_opinion_and_national_ defence_2013_march.pdf, 30; Saar Poll, Public Opinion and National Defence, October 2013, http://www.kmin.ee/sites/default/files/elfinder/article_files/public_opinion_and_national_defence_2013_ oct.pdf, 30; Saar Poll, Public Opinion and National Defence, March 2014, http://www.kmin.ee/sites/ default/files/elfinder/article_files/public_opinion_and_national_defence_2014_march.pdf, 29; Turuuuringute, Public Opinion and National Defence, November 2014, http://www.kmin.ee/sites/default/files/elfinder/article_files/public_opinion_and_national_defence_2014_ nov_0.pdf, 28; Turu-uuringute, Public Opinion and National Defence, October 2016, http://www.kmin. ee/sites/default/files/elfinder/article_files/public_opinion_and_national_defence_2016_october.pdf, 29; Turu-uuringute, Public Opinion and National Defence, autumn 2018, http://www.kmin.ee/sites/default/files/elfinder/article_files/public_opinion_and_national_defence_2018_ october_0.pdf, 32; Turu-uuringute, Public Opinion and National Defence, March 2019, 39.

${ }^{48}$ WIN/Gallup International, WIN/Gallup International Global Survey Shows Three in Five Willing to Fight for Their Country, 5.

${ }^{49}$ SKDS, Latvijas iedzīvotāju viedoklis par valsts aizsardzības jautājumiem, 42.

${ }^{50}$ Andžāns et al., Psihologískā aizsardzība Latvijā: ievainojamības un iespējas, 17.

${ }^{51}$ Ramonaitè et al., Kas eitu ginti Lietuvos?: pilietinio pasipriešinimo prielaidos ir galimybès.

${ }^{52}$ Phrasing of questions differ, as explained in the chapter. It is based on sources mentioned in this section, excluding secondary sources. In some years, results from one or more surveys for the same country are included.
} 
The results of the mapping have to be approached with a certain degree of caution. The regularity of the surveys across the Baltic States varied: with the highest rate in Estonia (comparable annual data is available from 2001 to 2019) and the lowest frequency in Lithuania and Latvia (for example, no data is available there for the majority of the first decade of the 2000s). In addition to this, the questions given to the respondents as well as the answer options and granularity of the resulting data differ among various studies. For example, at least five different questions have been asked: "Of course, we all hope that there will not be another war, but if it were to come to that, would you be willing to fight for your country?"53; "If there were a war that involved [country], would you be willing to fight for your country?" 54 ; If [country] is attacked, are you ready to participate in defence activities using your own competence and skills?"55; "If necessary, I am ready to fight with arms to defend [country]"56; "If [country] was attacked, should inhabitants of [country], in your opinion, take up arms to defend themselves in all situations, even if the outcome seemed uncertain?" 57

At the same time, the benefits of generalizing results outweigh the aforementioned caveat. As Figure 1 shows, data gathered in different surveys provides broadly consistent trends. Only in some occasions there are significant deviations for one country in the same year or in the following years. Also, importantly, most of the surveys are representative at the respective national level (most samples include around one thousand respondents and most of them were conducted as face-to-face interviews).

Figure 1 allows concluding that the highest willingness to defend one's own country was observed in 1990 when all three Baltic States had just declared independence from the Soviet Union and the patriotic sentiment was probably at an all-time high (their formal independence and international recognition was achieved in 1991). Data from the 1990s is parsimonious in all three countries, though the available data shows a significant decrease in the willingness to defend all three countries. In the first decade of $21^{\text {st }}$ century the most consistent and frequent data is available for Estonia, where polls were conducted annually (in some years even three times a year). In general, Figure 1 demonstrates that the highest levels of the willingness to defend one's own

\footnotetext{
${ }^{53}$ European Values Study, EVS 1990 - Variable Report Integrated Dataset, 561; "WVS Wave 6 (2010-2014)," World Values Survey.

${ }^{54}$ WIN/Gallup International, WIN/Gallup International Global Survey Shows Three in Five Willing to Fight for Their Country, 3.

${ }^{55}$ In researches conducted for the Ministry of Defence of Estonia at least since 2012. See reference 47.

${ }^{56}$ SKDS, Latvijas iedzīvotāju viedoklis par valsts aizsardzības jautājumiem, 42.

${ }^{57}$ Andžāns et al., Psihologiskā aizsardzība Latvijā: ievainojamības un iespējas, 17.
} 
country have consistently been observed in Estonia, while the lowest levels were in Lithuania and Latvia.

\subsection{The intra-societal dimension in 2019}

As underlined by Díez-Nicolás, the level of the willingness to fight for one's own country often varies more considerably inside one country than within a region..$^{58}$ Therefore, this chapter presents a detailed reflection of various factors influencing people's willingness to defend their own country, specifically in regards to Estonia, Latvia, and Lithuania.

A representative sociological survey was conducted in all three Baltic States to test the hypotheses examined in this article. Altogether, it involved 2,763 respondents (the number of completed interviews) aged from 18 to 74 : 870 of them in Estonia, 1,001 in Latvia, and 892 in Lithuania; the respondents were identified by applying the multi-stage proportional representation method. Interviews in Lithuania were conducted by Baltijos Tyrimai from 14 to 27 November 2019, by SKDS in Latvia from 28 November to 8 December 2019, and by Turu-uuringute in Estonia from 28 November to 8 December of the same year.

The following question was given to the respondents: "If [Estonia, Latvia, or Lithuania] was attacked, should inhabitants of [Estonia, Latvia, or Lithuania], in your opinion, take up arms to defend themselves in all situations, even if the outcome seemed uncertain?" 59 This question is a translation of a question used in surveys in Sweden since $1952^{60}$ and in Finland since $1970 .{ }^{61} \mathrm{It}$ has also been previously employed in a research in Latvia in $2017 .^{62}$

\footnotetext{
${ }^{58}$ Díez-Nicolás, “Cultural Differences on Values about Conflict, War and Peace," 264.

${ }^{59}$ The question in Estonian language - "Kui Eestit rünnataks, kas siis Teie arvates peaksid Eesti elanikud end igal juhul kaitsma, relv käes, isegi kui tulemus paistaks ebakindel?"; in Latvian language - "Ja Latvijai uzbruktu, vai Latvijas iedzīvotājiem, Jūsuprāt, būtu ar ieročiem jāaizstāv sevi visās situācijās, pat tad, ja iznākums šḳistu neskaidrs?"; in Lithuanian language - "Kaip Jūs manote, jeigu Lietuva būtų užpulta, Lietuvos gyventojai turètų patys apsiginti ginklu visais atvejais net, kai pasekmès būtų nenusakomos?"; in Russian language (asked in Estonia and Latvia) - "Если бы на Эстония напали, на Ваш взгляд, жителям Эстония надо было бы защищать себя с оружием в руках в любых ситуациях, даже тогда, когда исход был бы неясен?”

${ }^{60}$ The question in Swedish - "Antag att Sverige anfalls. Tycker du att vi bör göra väpnat motstånd även om utgången för oss verkar oviss?” (Swedish Civil Contingencies Agency, Opinioner 2012, https://www.msb. se/RibData/Filer/pdf/26586.pdf, 85.).

${ }^{61}$ The question in Finnish - "Jos Suomeen hyökätään, niin olisiko suomalaisten mielestänne puolustauduttava aseellisesti kaikissa tilanteissa, vaikka tulos näyttäisi epävarmalta?" ("Willingness to defend the country," Statistics Finland, last modified December 14, 2018, https://findikaattori.fi/en/77.). ${ }^{62}$ Andžāns et al., Psihologiskā aizsardzība Latvijā: ievainojamības un iespējas, 17.
} 
Compared to the question used in the European Values Study, the World Values Survey and WIN/Gallup International Global Survey, this question underlines the defensive nature of the activity. Secondly, it mentions taking up arms, though this does not imply that a country can be defended with arms only (of course, there is a wide range of non-military activities of similar importance), it thus tests the ultimate margins of the respondents' intentions. The notion of taking up arms has also been used in surveys conducted for the purposes of defence ministries in Latvia and Estonia (as mentioned above, the Estonian surveys are the ones most frequently conducted in the Baltic States). Third, the question addressed to the respondents assumes the uncertainty of the outcome of a possible attack; again, aiming to test the ultimate margins of the respondents' intentions.

As visualized in Figure 2, the results of this survey point to similar trends with previous researches. The willingness to defend one's own country is the highest in Estonia (66.6 percent), which demonstrates the levels similar to the Nordic countries. ${ }^{63}$ The willingness to defend one's country is the lowest in Lithuania (29.9 percent), thus leaving Latvia in the middle (49 percent). Estonia also presents the lowest number of the respondents who were not able to provide either an affirming or dissenting answer (at 11.2 percent, which is almost two times lower than in Latvia and Lithuania).

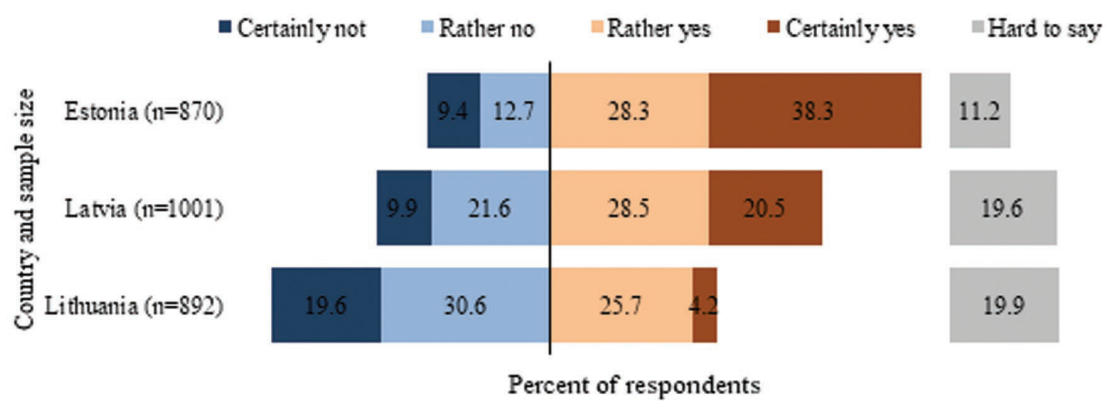

Figure 2. The willingness to defend one's own country in Estonia, Latvia, and Lithuania in 2019. ${ }^{64}$

\footnotetext{
${ }^{63}$ For example, in 2019, answer to an identical answer in Finland was 68 percent ("Willingness to defend the country," Statistics Finland.).

${ }^{64}$ Answers to question - "If [Estonia, Latvia and Lithuania accordingly] was attacked, should inhabitants of [Estonia, Latvia and Lithuania accordingly], in your opinion, take up arms to defend themselves in all situations, even if the outcome seemed uncertain?"
} 
The results of the survey suggest that in all three countries male individuals are more likely to defend their country than female respondents. Similarly, the respondents speaking the official language of the countries are more likely to be willing to defend their country than those speaking Russian in their families. Also, the respondents with secondary or vocational secondary education are more likely to be willing to defend their country.

The data of the survey is presented in more detail below:

- In Estonia, men are more likely to defend their country (72.1 percent) compared to women (61.5 percent); individuals aged 64 to 74 (74.4 percent) compared to those aged 18 to 24 (54.3 percent); Estonian-speakers (75.1 percent) compared to Russian-speakers (49 percent); persons with secondary or vocational secondary education (69.3 percent) compared to those with higher education (61.4 percent); and respondents living in Western-Estonia (78.5 percent) compared to those living in North-East of the country (53.3 percent);

- In Latvia, men are more likely to defend their country (53.3 percent) compared to women (44.9 percent); individuals aged 45 to 54 (54.7 percent) compared to those aged 64 to 74 (43.3 percent); Latvian-speakers (55.1 percent) compared to Russian-speakers (40.1 percent); persons with secondary or vocational secondary education (50.9 percent) compared to those with higher education (44.1 percent); and respondents living in Vidzeme Region (52.4 percent) compared to those living in Latgale Region (40.8 percent);

- In Lithuania, men are more likely to defend their country (35.7 percent) compared to women (24.8 percent); individuals aged 18 to 24 (39.6 percent) compared to those aged 55 to 63 (20.1 percent); Lithuanianspeakers (30.6 percent) compared to Russian-speakers (26.9 percent); persons with secondary or vocational secondary education (31.5 percent) compared to those with basic education (20.3 percent); and respondents living in Telšiai District (59.9 percent) compared to those living in Utena District (9.8 percent).

\section{Inter-societal and intra-societal hypotheses and the case of the Baltic States}

The first hypothesis (H.1.1) is based on Inglehart et al., who developed a detailed toolkit for verification in their research. The main indicators of their toolkit include "Pro-choice Values", "Democratic Freedoms Index", "Life 
Opportunities Index I and II", and "International Cooperation". 65

This toolbox is not entirely applicable to the Baltic States, because of scarcity of reliable and consistent data on the pro-choice values. ${ }^{66}$ "Democratic Freedom Index" can be assessed based on data from the Freedom House, which is also used by Inglehart et al. The Index of the Freedom House classifies all three Baltic States as "free" from 1991 onwards, with the exception of the "partly free" status for Latvia from 1992 to 1993 and Estonia in 1992. The data from the same source suggests that the state of freedoms and liberties has increased in all three countries since 1991, with Estonia and Lithuania currently ranking ahead of Latvia. ${ }^{67}$ While all three countries have significantly progressed, when it comes to political and civil rights, the willingness to defend each country by their citizens has generally decreased (see the linear lines in Figure 1). Meanwhile, a more nuanced analysis raises questions in regards to the direct link between the "Democratic Freedom Index" and the willingness to defend one's own country. For example, despite stable and slightly improving levels of freedom levels in Estonia and Latvia since 2014, the willingness to defend these countries by citizens has slightly increased as well, contrary to what $H .1 .1$ would suggest.

Assessment of "Life Opportunities I and II": the data of the gross domestic product (hereafter referred to as the GDP) per capita, Gini index, life expectancy at birth, female fertility rate, tertiary enrolment ratio, and years of schooling indicates substantial growth in life opportunities in the Baltic States. Thus the third (multi-level) hypothesis of Inglehart et al. and H.1.1 would also predict a decrease in the willingness to defend one's country (the source of the data below is the World Bank to maximize similarity to Inglehart et al. and to ensure homogeneity):

- The GDP per capita increased from 1995 to 20187.5 times in Estonia, 7.8 times in Latvia, and 8.8 times in Lithuania (the GDP per capita decreased markedly in all three countries in 2009 and less so also in 2015). All three countries are classified in the high income group by the World Bank; ${ }^{68}$

\footnotetext{
${ }^{65}$ Inglehart et al., "Declining willingness to fight for one's country: The individual-level basis of the long peace," 5-10 (appendix).

${ }^{66}$ With reliable and consistent data here and further below we describe nationally representative data from primary sources from at least two decades accross all three Baltic states, so that they could provide similar trends as Figure 1 on willingness to defend one's country.

${ }^{67}$ Freedom House, HISTORICAL FIW STATUS AND RATINGS INFORMATION, https://freedomhouse. org/sites/default/files/Country\%20and\%20Territory\%20Ratings\%20and\%20Statuses\%20FIW1973-2018. xlsx; "Freedom in the World 2019," Freedom House, accessed December 27, 2019, https://freedomhouse. org/report/freedom-world/freedom-world-2019.

${ }_{68}$ "GDP per capita (current US\$)," World Bank, accessed December 27, 2019, https://data.worldbank.org/ indicator/NY.GDP.PCAP.CD.
} 
- Inequality decreased from 1993 to 2015 in Estonia by 6.8 Gini points, while it increased in Latvia and Lithuania by 7.2 and 3.8 Gini points respectively; ${ }^{69}$

- Life expectancy at birth increased in all three countries: from 1991 to 2017 it grew by 10.6 percent in Estonia, by 7.6 percent in Latvia, and by 5.8 percent in Lithuania (with decrease from 1991 to 1994 in all three countries); ${ }^{70}$

- Female fertility rate decreased in all three countries: from 1991 to 2017 it decreased by 11.1 percent in Estonia, by 6.5 percent in Latvia, and by 15.9 percent in Lithuania (with a significant fall in early 1990s, while going up in all three countries from 2005 and then again from 2013); ${ }^{71}$

- School enrolment rate increased in all three countries: from 1991 until 2017 it increased by 45.3 percent in Estonia, by 62.4 percent in Latvia, and by 40.3 percent in Lithuania (with a steep rise in all three countries from mid 1990s)..$^{72}$

To continue with H.1.1, a simplified approach is used to measure "International Cooperation" compared to the Political Globalisation Index of Dreher, Gaston, and Martens, ${ }^{73}$ which was employed by Inglehart et al. In the case of the Baltic States, the likely findings are self-evident because all three countries are well integrated in the field of international cooperation, especially since 2004. They are members of the NATO, the EU, the Organisation for Economic Co-operation and Development (hereafter referred to as the OECD) and various other regional and global organizations; all three countries have presided over the Council of the EU and two of them were elected to the Security Council of the United Nations; all three countries actively participate in military and civilian missions and operations abroad and host the armed forces of other NATO countries.

Regarding H.1.1, it can be concluded that all three Baltic States have experienced a strong growth in life opportunities since the beginning of 1990s, as shown by the data on the GDP per capita, life expectancy, female fertility

\footnotetext{
69 "GINI index (World Bank estimate)," World Bank, accessed December 27, 2019, https://data.worldbank. org/indicator/SI.POV.GINI.

70 "Life expectancy at birth, total (years)," World Bank, accessed December 27, 2019, https://data. worldbank.org/indicator/SP.DYN.LE00.IN.

71 "Fertility rate, total (births per woman)," World Bank, accessed December 27, 2019, https://data. worldbank.org/indicator/SP.DYN.TFRT.IN.

72 "School enrollment, tertiary (\% gross)," World Bank, accessed December 27, 2019, https://data. worldbank.org/indicator/SE.TER.ENRR.

${ }^{73}$ Axel Dreher, Noel Gaston, and Pim Martens, Measuring Globalisation: Gauging its Consequences (New York: Springer, 2008).
} 
rate, school enrolment rate (the only inconclusive indicator for all three countries is the economic inequality, which has decreased only in Estonia). Indeed, as H.1.1 would predict, the willingness of the residents of these countries to defend them has decreased since the early 1990s along with higher life opportunities (see Figure 1). However, the data from the early 1990s on the willingness to defend one's country is scarce and specific to each case. Also, fluctuations of the data in some indicators in certain years do not necessarily result in either lower or higher level of the willingness to defend these countries. Furthermore, the willingness to defend Estonia and Latvia by their respective residents has been increasing slightly, but persistently, since around 2014, despite continued growth in life opportunities.

H.1.2 would suggest that societies with higher levels of national pride and confidence in the national armed forces and the government demonstrate higher levels of the willingness to fight. Correlation between the willingness to defend one's country and national pride is constrained by the scarcity of representative data from all three case studies. The closely associated correlation with the trust in the armed forces and the government is easier to verify. According to Eurostat, the highest trust in the national armed forces is observed in Estonia at 82 percent in 2019 (it has been consistently high from 2004 to 2019 , ranging from 72 percent to 82 percent). Lower levels of the trust are observed in Lithuania at 77 percent and Latvia at 68 percent (it has ranged from 45 percent in 2009 to 77 percent in 2019, and 44 percent in 2009 to 70 percent in 2019 respectively; only Latvia's indicator stands below the EU average). ${ }^{74}$ Compared to trust in the national armed forces, the situation with the trust in the national governments is different. The values are significantly lower in all three countries compared to the trust in the armed forces. The current highest level is in Estonia at 46 percent (with the lowest point at 34 percent in 2012 and a high of 66 percent in 2007) and in Lithuania also with 46 percent (with the lowest point there being at 13 percent in 2010 and 46 percent in 2019 as the highest one), though in retrospective the high percentage in Lithuania is rather an exception than a normality. The same level stands at 31 percent in Latvia (it has been between 9 percent in 2009 and 35 percent in 2005). ${ }^{75}$

To continue with H.1.2, the trust in the armed forces and the government, as related variables, should be treated with caution. While the trust in

\footnotetext{
74 "Public Opinion," European Commission, accessed December 27, 2019, https://ec.europa.eu/ commfrontoffice/publicopinion/index.cfm/Chart/getChart/themeKy/18/groupKy/82.

75 "Public Opinion," European Commission, accessed December 27, 2019, https://ec.europa.eu/ commfrontoffice/publicopinion/index.cfm/Chart/getChart/chartType/lineChart//themeKy/18/ groupKy/98/savFile/54.
} 
the national armed forces is rather high in all three Baltic States, the trust in the respective governments is significantly lower in each and every one of them. In terms of both indicators, the highest level of the trust is recorded in Estonia and thus it correlates with the higher level of the willingness to defend that country. Meanwhile, there are fewer parallels between both the trust variables and the willingness to defend the country in Lithuania and in Latvia: if the trust in the armed forces in both countries is relatively high, it is not the case with the willingness to defend their own country, especially in the case of Lithuania.

H.1.3 noted the past humiliation in wars and current external threats were impacting the will to defend one's country. In the case of the Baltic States, both such past and contemporary factors are related to Russia. All three countries were occupied by the Soviet Union in 1940 and, after regaining independence in 1991, they have had uneasy relations with Russia. Russia is broadly seen as the main threat to their national security, especially so since the armed conflict between Russia and Ukraine commenced. ${ }^{76}$ However, it has not resulted in a uniform impact on the willingness to defend their country in all three Baltic States. As Figure 1 above demonstrated, the willingness to defend Lithuania has decreased since 2014 when the armed conflict between Russia and Ukraine started. At the same time, the willingness to defend Estonia and Latvia has slightly increased since the time when the events in Ukraine unfolded. This suggests that history and the current conflicts probably are not the main contributors to higher levels of the willingness to defend one's own country. This can be explained by different perceptions among Estonian-speakers and Latvian-speakers versus Russian-speakers. These can be attributed to both differences in historical memory and perceptions of current socio-political processes, partly resulting from external influence in domestic information spaces. ${ }^{77}$

According to the data revealed by the survey conducted for this article, if the willingness to defend one's own country in Estonia and Latvia is measured among Latvian-speakers and Estonian-speakers only, both standing

\footnotetext{
${ }^{76}$ Parliament of Estonia, National Security Concept of the Republic of Estonia; Parliament of Latvia, The National Security Concept; Parliament of Lithuania, National Security Strategy of the Republic of Lithuania.

${ }^{77}$ For example, most of Russian-speakers in Latvia consume not only Russian-language but also Russianstate media where anti-Baltic and anti-Western sentiments are widespread. A sociological research in 2017 found that 80 percent of non-Latvians (predominantly Russian-speakers) acquire information and entertain themselves from sources in Russian language; among their 12 most trusted sources, six are Russian state products (Latvijas Fakti, Latvijas iedzīvotāju medijpratība. Kvantitatìvais pētījums, June 2017, https://www.km.gov.lv/uploads/ckeditor/files/mediju_politika/petijumi/Medijpratiba_petijuma\%20 rezultati_Latvijas\%20Fakti_18_07_2017.pdf, 7, 12.).
} 
at 75.1 percent and 55.1 percent accordingly, this would be among the highest indicators in the Nordic-Baltic region. ${ }^{78}$ At the same time, even though the respective levels are lower among Russian-speakers and stand at 49 percent and 40.1 percent accordingly, they are not among the lowest ones in this regional context; they are even higher than the common level in Lithuania (there, the difference between Lithuanian-speakers and Russian-speakers is only 3.8 percent, compared to 26.1 percent and 15 percent in Estonia and Latvia respectively). Similar differences among Estonian-speakers and Latvian-speakers, on one hand, and Russian-speakers, on the other, have been observed in previous researches as well. ${ }^{79}$

The aforementioned review of Gini index above allows us to test H.1.4 suggesting that societies with higher income inequality demonstrate lower willingness to fight. Data, as presented above, does not lead directly to conclusions. More recent data from Eurostat is broadly similar to that of the World Bank, ranking Lithuania and Latvia as the second and third countries with the highest inequality in the EU as Estonia's index is around the EU average; ${ }^{80}$ a broadly similar picture can also be drawn from the data provided by the OECD.$^{81}$ Lithuania indeed presents the highest level of inequality and the lowest level of the willingness to defend one's country, while Estonia presents the opposite in both terms. However, the comparison of Lithuania and Latvia shows slight differences in inequality and considerable differences in the willingness to fight, thus causing some doubt in regards to the validity of H.1.4.

The second set of hypotheses, as indicated, refers to the intra-societal level. While there is no comparable and consistent data to test H.2.2 and H.2.3 on inequality and rationality of decisions of individuals respectively, more data is available on factors mentioned in H.2.1. This article confirms H.2.1 to the extent that male individuals are more likely to defend their country than female respondents. The legacy of perceiving defence and security as primarily a male activity domain apparently has played a role here. Otherwise, the findings on intra-societal hypotheses partially corroborate the results produced

\footnotetext{
${ }^{78}$ For example, in 2019, answer to an identical answer in Finland was 68 percent ("Willingness to defend the country," Statistics Finland.).

${ }^{79}$ Turu-uuringute, Public Opinion and National Defence, March 2019, 40 (to be fair, it has to be noted that in Estonia in the first decade of 2000s this difference has been smaller and in some years it has even been reverse); SKDS, Latvijas iedzīvotāju viedoklis par valsts aizsardzības jautājumiem, 43; Andžāns et al., Psihologiskā aizsardzība Latvijā: ievainojamības un iespējas, 17.

80 "Gini coefficient of equivalised disposable income - EU-SILC survey," Eurostat, accessed December 27, 2019, https://appsso.eurostat.ec.europa.eu/nui/submitViewTableAction.do.

81 "Income inequality," Organisation for Economic Co-operation and Development, accessed December 27, 2019, https://data.oecd.org/inequality/income-inequality.htm.
} 
by Rutkauskas, which concluded that national pride and confidence in both the armed forces and the governments were significant factors in an individual's willingness to defend one's country in case all three countries. ${ }^{82}$ While that can be somewhat observed in the case of Estonia, the same parallels are less straightforward in the other two countries. Furthermore, there is a clear divergence between the trust in the armed forces and the trust in other state institutions in all three countries.

It was already mentioned that alongside the issue of gender, factors related to age, education, religiousness, ideological views, and conscription have been discussed as impacting the willingness to defend one's country, although coming to different conclusions. Neither Rutkauskas, nor our 2019 survey established a uniform link in all three countries regardless of age and education, and the willingness to defend one's country. Rutkauskas noted that older people were less willing to defend their country in Estonia and Lithuania, while the opposite was found in Latvia; the survey here found that elderly Estonians were more willing to defend their country. In respect of education, Rutkauskas concluded that the respondents with a better education in Lithuania and Latvia were more willing to fight, which was contrary to Estonia $;{ }^{83}$ it was found here that in all three countries individuals, who were most willing to defend their countries, had a secondary or a vocational secondary education.

The impact of religiousness again is difficult to verify because of secularization and the data is unreliable. Estonia has consistently ranked among the least religious countries in the world, though the other two states were not observed to be among the most religious countries either. ${ }^{84}$ Secularization in Estonia was generally supported by the latest census showing that only 29 percent of the residents affiliated themselves with a religion ( 16 percent affiliated themselves with the Orthodox Church and 10 percent with Lutheranism).$^{85}$ Meanwhile, the latest census in Lithuania showed that 77.2 percent of the re-

\footnotetext{
${ }^{82}$ Rutkauskas, "Factors Affecting Willingness to Fight for One's Own Country: The Case of Baltic States," 60 .

${ }^{83}$ Rutkauskas, "Factors Affecting Willingness to Fight for One's Own Country: The Case of Baltic States," 57-61.

84 “Least Religious Countries 2020," World Population Review, last modified November 6, 2019, http:// worldpopulationreview.com/countries/least-religious-countries/; "How do European countries differ in religious commitment? Use our interactive map to find out," Pew Research Center, last modified December 5, 2018, https://www.pewresearch.org/fact-tank/2018/12/05/how-do-european-countries-differ-in-religiouscommitment/. 85 "PHC 2011: OVER A QUARTER OF THE POPULATION ARE AFFILIATED WITH A PARTICULAR RELIGION,” Statistics Estonia, last modified April 29, 2013, https://www.stat.ee/news-release-2013050 ?highlight=religion.
} 
sidents denoted themselves as Roman Catholic. ${ }^{86}$ Questions on religion were not a part of the latest census in Latvia, other official sources only provided the number of religious congregations (they placed Lutheran, Roman Catholic, and Orthodox congregations ahead of others).$^{87}$ Assessment of the situation is further complicated because the actual situation might differ even further as even religiously affiliated individuals differ in their commitment to defending their country. On the other hand, the past and current impact of religious values should not be underestimated, even in secular societies. As with most surveys, the one conducted for this article does not allow us to establish a direct link between religion and the willingness to defend one's country. Only general assumptions can be made, based on separately acquired data linking the willingness to defend one's own country and religion.

Last but not least, the issue of conscription has recently been on the agenda in the Baltic States as a result of external threats. Different models of conscription are employed in Estonia and Lithuania (in the latter it was reintroduced in 2015 as a reaction to the armed conflict between Russia and Ukraine), while in Latvia it was abolished in 2007 and has not been renewed since then. The levels of the willingness to defend one's country, as presented in Figure 1, do not provide conclusive regularities across all three countries. In Estonia, where conscription enjoys widespread support in society, ${ }^{88}$ the willingness to defend one's own country is high, while it is low and has decreased even more in Lithuania since the reintroduction of conscription.

\section{Conclusions}

The issue of the willingness to defend one's own country is an important part of the debate on country's defensibility and society's security. The scope and strength of the willingness is both a symptom and a factor in a range of the societal-level and individual-level attitudes towards political, societal, and economic processes in respective countries. The individual willingness directly correlates with societal resilience to withstand external and internal threats and challenges. The debate on the individual preferences and choices in the

\footnotetext{
86 "Ethnicity, mother tongue and religion," Statistics Lithuania, last modified March 15, 2013, https://osp. stat.gov.lt/en/web/guest/informaciniai-pranesimai?articleId=223122.

${ }^{87}$ Central Statistical Bureau of Latvia, Statistical Yearbook of Latvia, 2020, https://www.csb.gov.lv/ sites/default/files/publication/2019-12/Nr_01_Latvijas_statistikas_gadagramata_2019_Statistical\%20 Yearbook\%20of\%20Latvia_\%2819_00\%29_LV_EN.pdf, 112.

${ }^{88}$ Turu-uuringute, Public Opinion and National Defence, March 2019, 52.
} 
security context is inclusive and extensive and stretches far beyond the military sector. With the opportunities and challenges brought by digitalization and weaponization of the digital information space, the willingness to defend one's own country becomes subjected to unintentional and intentional external influences: ranging from a more diverse outlook about the situation in the country to the country's exposure to external attempts diminishing trust and the willingness to defend that country. Value systems, political legitimacy, perceptions and practice of patriotism, efficiency of democratic institutions are among the important variables that contribute to resilience of the society and also shape specific individual preferences, including the willingness to defend one's own country.

This article reviewed and provided empirical evidences to test several hypotheses on the willingness to defend one's own country or lack of it. These were classified into inter-societal and intra-societal categories. They were tested in the case of Estonia, Latvia, and Lithuania along with other factors that might have influenced the willingness to defend one's own country. Among the factors reviewed were life opportunities, confidence in the armed forces and the government, history and external threats, income inequality, gender, religiousness, age, education, and conscription.

Multiple surveys across three decades suggest that among the Baltic States the willingness to defend one's own country is the highest in Estonia but the lowest in Lithuania. The case of the Baltic States broadly affirms the hypothesis that growth in life opportunities has a negative impact on the widespread willingness to defend one's own country. However, each country has also its own specifics and trajectories. The high level of the willingness in Estonia along with the considerable growth in life opportunities over the past three decades points towards similar observations made by other researchers in relation to the Nordic countries where the willingness to fight is high despite higher life opportunities. However, growth in life opportunities cannot explain fluctuations in the levels of the citizens' willingness to defend their respective Baltic States, especially in the case of Lithuania.

The variation in the findings involving the willingness to defend across the three cases, with some exceptions in regards to life opportunities and gender, invites us to conclude that, despite certain general worldwide and regional trends, the willingness to defend one's own country depends on a combination of factors that are country-specific rather than region-specific. Furthermore, combinations of inter-societal and intra-societal determinants are not static and vary over time. Thus, future researches could use case-oriented designs 
and more in-depth methodologies to capture the specific and dynamic causal mechanisms that underpin people's preferences and motivations to defend their country. Also, doors remain open for further more general conceptual deliberations on correlation and synergy of the individual willingness to defend one's own country and evolving character and challenges to democratic societies.

December 2019 